\title{
The Physiologic and Radiologic Outcomes of Decortication for Chronic Empyema in the Long Term Follow Up: A Retrospective Analysis
}

\author{
Kronik Ampiyem Nedeni Ile Yapılan Dekortikasyonun Fizyolojik ve Radyolojik Uzun Dönem Sonuçlarl: \\ Retrospektif Çalısma
}

\author{
Ali Cevat Kutluk', Hasan Akın', Halil íbrahim Erdoğdu² \\ ${ }^{1}$ Department of Thoracic Surgery, Health Sciences University, İstanbul Yedikule Chest Diseases and Thoracic Surgery Practice and \\ Research Hospital, Istanbul; ${ }^{2}$ Kafkas University Medical Faculty, Department of Internal Medicine, Kars, Turkey
}

\begin{abstract}
Aim: Chronic empyema due to non-specific or tuberculosis lead to both decrease in pulmonary functions and distortions of the radiologic views. Decortication either through video assisted thoracic surgery (VATS) or open thoracotomy is the last resort of treatment. The study aims to evaluate the spirometry and radiologic outcomes of decortication of patients with chronic empyema.

Material and Method: The study included all patients who had decortication due to thoracic empyema between 2010 and 2016. Besides routine clinical evaluation spirometry analyses and radiologic evaluation with thoracic computerized tomography (CT) were performed in all patients. Either open thoracotomy with muscle sparing technique or VATS were performed to remove thickened parietal pleura and to decorticate the thickened pleura trapping the lung parenchyma. Change in the spirometry parameters were calculated. The improvement in the radiologic appearance were classified as satisfactory, moderately satisfactory, and unsatisfactory.

Results: A total of 104 patients comprised the study population. Sixty-eight of the cases (65\%) were male and the mean age of patients was $38.61 \pm 17.38$ years. Operation site was equally distributed. Non-specific microorganisms were the dominant etiologic agents rather tuberculosis. All spirometry parameters improved significantly. Both forced expiratory volume in one second (FEV1) and forced vital capacity (FVC) values increased after the decortication significantly. All patients were followed at least for 2 years. Most of the cases showed satisfactory results (92 cases, 88\%), 9 patients improved moderately (8.6\%), and only 3 patients (3\%) had unsatisfactory radiologic evaluation.
\end{abstract}

Ali Cevat Kutluk, Department of Thoracic Surgery, Health Sciences University, Istanbul Yedikule Chest Diseases and Thoracic Surgery Practice and Research Hospital, Istanbul34020,Turkey, Tel.05056309187Email.dralikutluk@gmail.com

Geliş Taribi: 26.02.2019 • Kabul Taribi: 07.03.2019
Conclusion: Decortication either through open thoracotomy or VATS approach is very effective treatment method to improve the spirometry parameters and restore the distorted radiologic appearances in patients with chronic empyema.

Key words: decortications; empyema; thoracoscopy; surgery

\section{ÖZET}

Amaç: Tüberküloz veya non-spesifik enfeksiyonlarnedenli kronik ampiyem hem akciğer fonksiyonlarında azalmaya hem de radiolojik bozulmalara yol açar. Açık vaya video yardımlı torasik cerrahi (VATS) yoluyla yapılan dekortikasyon en son bașvurulan tedavi yöntemidir. Bu çalıșmanın amacı kronik ampiyem nedeni ile dekortikasyon yapılan hastaların akciğer fonksiyonlarındaki ve radyolojik görünümlerindeki değișimlerin incelenmesidir.

Materyal ve Metot: Bu çalıșmaya 2010 ile 2016 yılları arasında kronik ampiyem nedeni ile dekortikasyon uygulanan hastalar dahil edilmiștir. Bütün hastalarda rutin klinik tetkiklerin yanısıra spirometry analizleri ve bilgisayarlı toraks tomografileri (BT) değerlendirilmiștir. Kalınlașmıș parietal plevrayı rezeke etmek ve akciğeri saran korteksi soymak için ya açık torakotomi ya da VATS yöntemi kullanıldı. Spirometri değerlerindeki değișimler hesaplandı. Radiolojik görünümdeki iyileșmeler tatminkar, orta tatminkar ve tatminkar değil olarak derecelendirildi.

Bulgular: Çalıșmaya 104 hasta alındı. Hastaların 68'i (\%65) erkek olup yaș ortalaması 38,61 $\pm 17,38$ olarak hesaplandı. Operasyon tarafı eșit dağılımlıydı. Non-spesifik mikroorganizmalar tüberküloza göre daha baskın etiolojik ajanlardı. Hem birinci saniyedeki zorlu hacim (FEV1) hem de zorlu vital kapasite (FVC) operasyondan sonra anlamlı olarak iyileșme gösterdi. Bütün hastalar en az 2 yıl takip edildi. Radyolojik değerlendirmede hastaların çoğu (92 hasta, \%88) tatminkar, 9 hasta $(\% 8,6)$ orta derecede tatminkar ve $3(\% 3)$ olgu da tatminkar olmayan olarak sonuçlandı.

Sonuç: Açık veya VATS yoluyla yapılan dekortikasyon kronik ampiyemli hastaların tedavisinde spirometry değerlerinde iyileșme sağlayan ve radyolojik bozulmaları iyileștiren etkili bir tedavi yöntemidir.

Anahtar kelimeler: dekortikasyon; ampiyem; torakoskopi; cerrahi 


\section{Introduction}

Although the advances in the era of antibiotics and the availability of better medical care of the infected patient thoracic empyema is still a challenge for both chest physicians and thoracic surgeons. Even in developed countries, empyema affected 65000 people in each year ${ }^{1}$. As a developing country, the empyema issue is more profound in this country due to national and international immigration.

Although parapneumonic types of pneumonia are the primary cause for decortications, tuberculous empyema is not less frequent than parapneumonic effusions. The first stage of empyema, exudative phase, is characterized by bright, thin serous effusion which is followed by the second phase, fibrinopurulent phase, in which the effusion becomes thick and purulent. The third and last phase is the organizing phase which results in the formation of granulation tissue with thickened visceral and parietal pleura ${ }^{2}$.

Usually, the stage of the empyema determines the method of treatment. In the first stage, a tube thoracostomy is usually enough to relieve the problem. In the second phase, fibrinolytic agents or mechanical deloculation of the pleural cavity are added to the first method. Decortication either via thoracotomy or video-assisted thoracoscopic surgery (VATS) is required to alleviate the patient ${ }^{3}$.

In this study, we reviewed the records of patients who undergone decortication due to empyema and evaluated the improvements in the respiratory functions and radiologic changes of the affected hemithorax.

\section{Material and Method}

The records of all patients with pleural effusion between January 2010 and December 2016 were analyzed retrospectively. The study population consisted of all patients who underwent pulmonary decortication due to chronic empyema. The study was approved by the ethical committee of a teaching research hospital (2011-KAEK-50). The records of these patients were analyzed retrospectively in terms of age, sex, etiology, localization, comorbidities, hemoglobin levels, sedimentation rates, operation time, blood loss, hospital stay, and complications. The main indications for decortication were trapped lung and thickened parietal or visceral pleura. Medically unstable cases, patients who refused the operation, and cases with insufficient data were excluded from the study.
The main bulk of patients was referred to as the surgery from chest clinics of the same hospital. The treatment methods other than decortications were tried before the patient referred to surgery. They all completed the usual clinical and laboratory workup including specific and non-specific microbiological cultures and received the appropriate treatment when necessary.

All patients deemed for decortication were evaluated by a team consisting of thoracic surgeons and chest physicians. Initial physical examinations and blood chemistry analysis were performed. Respiratory function tests were measured including vital capacity (VC), forced vital capacity (FVC), and forced vital capacity in the first second (FEV1). Posteroanterior (PA) chest radiographs and thoracic computerized tomography (CT) were taken in all cases.

After intubating the patients with double lumen endotracheal tubes either posterolateral thoracotomy or in selected cases VATS was used. VATS was used in selected cases since 2014. The parietal pleura were removed to provide mobility to the thoracic cage and diaphragm. The cortex overlying the lung was removed to provide the lung to re-expand. Pulmonary lacerations and air leaks occurring during the operation were handled by primary suturing and fibrin glue application when necessary.

All cases were taken to the intensive care unit after the operation, and patient-controlled analgesia with meperidine $5 \mathrm{mg} / \mathrm{kg}$ was given to control the pain. Patients were mobilized as soon as possible, and pulmonary physiotherapy was started. After removing the chest tubes, the patients were discharged for follow-up. Respiratory function tests were measured, and chest roentgens were taken at the first, third, sixth months and first and second year of the operation. Thorax CT was taken in the third month and first and second year of the operation.

\section{Statistical Analysis}

Due to the nature of the study sample size was calculated. Categorical data are presented as a frequency (\%) and continuous data as a mean with standard deviation $(\mathrm{SD})$. Chi-square test was used to compare the differences in binary and categorical data. The MannWhitney $U$ test was applied to compare the means between independent groups and the paired t-test applied to compare the means of the same patients. SPSS 17.0 (SPSS Inc, Chicago, IL) package program was used and $p<0.05$ was considered significant. 


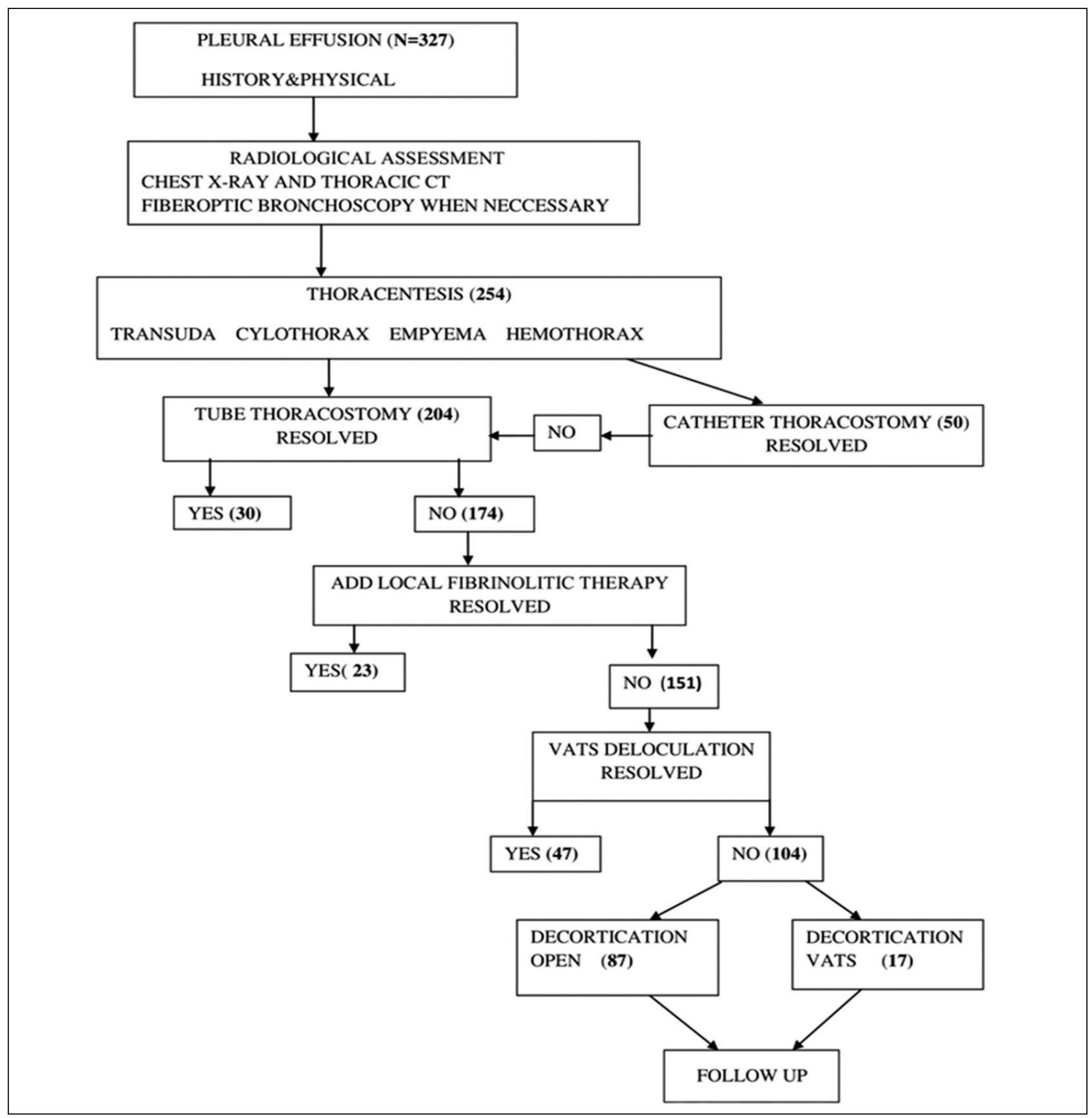

Figure 1. Flow-chart of patients treated due to pleural effusion.

\section{Results}

During the study time, a total of 327 cases were treated due to pleural effusion. About one-third of these (104 cases) underwent decortication either by open or VATS approach (Figure 1). Sixty-eight of the cases $(65 \%)$ were male, and the mean age of patients was $38.61 \pm 17.38$ years. Operation site was equally distributed. Non-specific microorganisms were the dominant etiologic agents rather tuberculosis. A total of 61 complications occurred in 34 patients (32\%). The most frequent complication was prolonged air leak (Table 1).

All spirometry parameters improved significantly. Both forced expiratory volume in one second (FEV1) 
and forced vital capacity (FVC) values increased after the decortication significantly (Table 2). All patients were followed at least 2 years. Both chest x-ray and thoracic computerized tomography were taken to evaluate the radiologic improvement. Most of the cases showed satisfactory results (92 cases, $88 \%$ ), nine patients improved moderately $(8.6 \%)$, and 0nly three patients (3\%) had an unsatisfactory radiologic evaluation (Figure 2).

Table 1. Clinical characteristics of patients with decortication

\begin{tabular}{lc}
\hline Study population & 104 \\
Sex (Male/Female) & $68(65 \%)$ \\
& $36(35 \%)$ \\
Age (years) & $38.61 \pm 17.38$ \\
Localization (Right/Left) & $57(55 \%)$ \\
& $43(45 \%)$ \\
Etiology & \\
$\quad$ Non-specific & $88(84.6 \%)$ \\
Tuberculosis & $16(15.4)$ \\
Surgical approach (Open/VATS) & $87(83.6 \%)$ \\
& $17(16.4 \%)$ \\
Co-morbidities (DM, Hypertension, COPD) & 23 \\
Hemoglobin (g/dL) & $11.7 \pm 1.6$ \\
Sedimentation & $51.6 \pm 17.8$ \\
Operation time (minutes) & $128 \pm 21.32$ \\
Blood loss (mL) & $321 \pm 40.1$ \\
Drainage time (days) & $5.7 \pm 1.9$ \\
Hospital stay (days) & $6.2 \pm 2.1$ \\
Complications & \\
Prolonged air leak & 32 \\
Hemorrhage & 2 \\
Chylothorax & Wound infection \\
Renal failure & 13 \\
Arrythmia & 12 \\
vaTS, video-assisted thoracoscopic surgery; DM, diabetes mellitus; COPD, chronic obstructive \\
pulmonary disease.
\end{tabular}

Table 2. Comparison of spirometry parameters before and after the operation

\begin{tabular}{lccc}
\hline & Before & After & $P$ \\
\hline FEV1 & $2.2 \pm 0.7$ & $2.76 \pm 09$ & 0.001 \\
FEV1 (\%) & $65.1 \pm 13.8$ & $78.9 \pm 17.4$ & 0.001 \\
FVC & $2.6 \pm 0.7$ & $3.1 \pm 0.9$ & 0.001 \\
FVC (\%) & $61.4 \pm 10.4$ & $73.7 \pm 17.6$ & 0.001 \\
\hline
\end{tabular}

FEV1, forced expiratory volume in one second; FVC, forced vital capacity.

\section{Discussion}

Chronic empyema is the deposition of fibrin on the lung parenchyma and pleural space leading to trapped lung and thickened pleura. As a result, the lung loses its ability to expand which causes decreased ventilation, perfusion and oxygenation. Thickened pleura causes decreased thoracic wall compliance and even thoracic deformity. The fundamentals of the treatment are to remove the cortex on the parenchyma to provide the lung to re-expand and to remove the thickened pleura to provide the chest wall its mobility, especially relieve the diaphragm to be able to contract again ${ }^{4}$.

Though tuberculosis is prevalent in Turkey only $15 \%$ of the cases in the current series underwent decortications due to tuberculosis. In a large series from India, the rate tuberculous empyema occupied nearly $60 \%$ of the patients ${ }^{5}$. In contrast to this another series from Turkey Senol $^{6}$ reported on 309 cases with pleural empyema. Non-specific empyema accounted for $88 \%$ of the cases and only in $12 \%$ of the patients. Mycobacterium tuberculosis was the responsible microorganism.

Open thoracotomy and decortication have been the mainstay of the chronic empyema. However, there are many studies to evaluate the role of VATS in the treatment of chronic empyema ${ }^{1,5,7-10}$. Chen ${ }^{7}$ reported on one of the largest series with 274 patients who underwent decortications by VATS approach. They indicated that VATS was very successful in the treatment of empyema with no conversion to open thoracotomy, no mortality, or postoperative bleeding. Another series with 100 cases with empyema Kumar et al..$^{5}$ reported that in $10 \%$ of the cases VATS was converted to open thoracotomy. However, they pointed out that thoracoscopic decortications were very effective and safe with no postoperative mortality and short hospital stay.

In contrast to these studies favoring the use of VATS decortication in the treatment of empyema Subotic et al. ${ }^{1}$ was cautious for the use of VATS. He stressed that there were clear guidelines for the use of VATS decortications in the treatment of stage 3 empyema especially empyema with a long ( $>5$ weeks) symptomatic clinical history. Our experience in VATS decortications is limited, and we think that though VATS is useful for the early stages of empyema for deloculation, it can be used only in selected cases.

The main reason for decortications is to improve the decreased respiratory functions of the patients. Most of the series agree that decortications improve the 

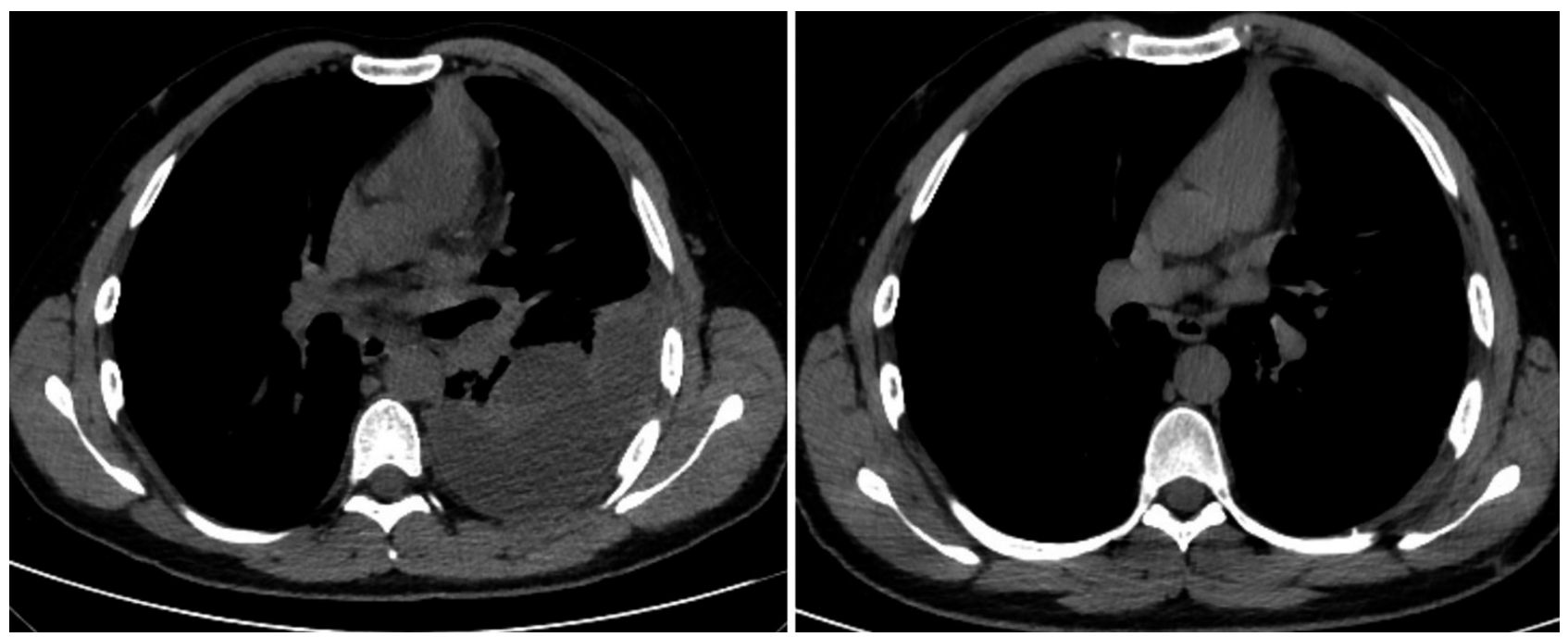

Figure 2. Pre- and postoperative view of a patient with satisfactory outcome.

pulmonary functions significantly ${ }^{4,11-13}$. Bagheri et al. ${ }^{4}$ studied 50 cases with chronic empyema and performed posterolateral thoracotomy in all patients. He pointed out that both FEV1 and FVC improved significantly after the operation. Another study with the same patient number stressed that thoracotomy not only improved the spirometry parameters significantly but also improved the thoracic asymmetry ${ }^{11}$. Choi et al. ${ }^{12}$ studied 41 tuberculous and 24 non-tuberculous empyema patients and concluded in both groups the operation improved the pulmonary functions significantly. Another study analyzing the factors useful on the pulmonary function after the decortication pointed out that age, gender, side of the disease, bacteriology or the duration of the empyema had no influence ${ }^{13}$.

Two other studies report on different designs and different outcomes. Okada et al. ${ }^{14}$ reported 45 patients with chronic empyema due to different etiologies. The main difference from other studies in the literature is Okada compared to the quality of life after the operation rather than spirometry improvement. Another interesting study compared the success of debridement alone and decortication for empyema and concluded that there was no difference between the two techniques. However, the study groups were too small to decide whether debridement alone was equally effective ${ }^{15}$.

Another way of understanding the efficiency of decortications is the improvement in the radiologic appearance of the cases. Evaluation of the pre and postoperative chest $\mathrm{x}$-rays and chest CT's of the patients provide a parameter of the use of decortications. Yang et al. ${ }^{16}$ studied 23 patients who had decortications due to chronic pulmonary empyema and evaluated the outcome of decortications by measuring the volumes of the operated and non-operated lung by pre and postoperative CT-densitometry. The study concluded that decortication for CPE could improve the re-expansion of diseased and healthy lung. They also pointed out that the improvement of non-operated lung might be due to the overall improvement of chest wall elasticity. Another study with 13 cases evaluated the volume of lung parenchyma on chest CT and compared the CT findings with the pulmonary function tests ${ }^{17}$. They concluded that there was a significant negative correlation between FVC changes and the relative volume of the affected lung. They also stressed that FVC and FEV1 were found to be significantly and positively correlated with the relative volume of the empyema.

Only comparing spirometry changes is one of the limitations of the study. It did not include comparing blood gas analyses, pulmonary ventilation, and perfusion parameters. Another limitation is that the radiologic comparison is only based on subjective qualitative evaluation rather than objective quantitative scoring. The main reason for these limitations is the retrospective nature of the study. Despite its limitations in recent years, there are only a few studies in the literature specifically addressing the place of decortication in the treatment of chronic pulmonary empyema. 
Chronic pulmonary empyema has always been a challenge to thoracic surgeons. Decortication is safe and efficient to improve pulmonary functions significantly by providing lung re-expansion and chest wall mobility that can be validated by spirometry and chest CT as well. More studies with large numbers and more parameters especially evaluating radiologic improvement with more precise quantitative methods will better define the efficiency of decortication on chronic empyema.

\section{References}

1. Subotic D, Lardinois D, Hojski A. Minimally invasive thoracic surgery for empyema. Breathe 2018;14:302-10.

2. Light RW. Parapneumonic effusions and empyema. In: Light R. W. ed. Pleural Diseases 6th ed, Philadelphia, Lippincott Williams \& Wilkins, 2013:209-46.

3. De Souza A, Offner PJ, Moore EE, Biffl WL, Haenel JB, Franciose RJ, et al. Optimal management of complicated empyema. Am J Surg 2000;180:507-11.

4. Bagheri R, Haghi SZ, Dalouee MN, Rajabnejad A, Basiri $R$, Hajian T. Effect of decortication and pleurectomy in chronic empyema patients. Asian Cardiovasc Thorac Ann 2016;24(3):246-9.

5. Kumar A, Asaf BB, Lingaraju VC, Yendamuri S, Pulle MV, Sood J. Thoracoscopic decortications of stage 3 tuberculous empyema is effective and safe in selected cases. Ann Thorac Surg 2017;104(5):1688-94.

6. Senol C, Celik M, Uysal A, Halezeroglu S, Keles M, Urek S, et al. Tüberküloz ampiyemde tedavi yaklaşımları ve operasyon zamanlaması. GKD Cer1994;2:358-61.

7. Chen B, Zhang J, Ye Z, Ye M, Ma D, Wang C, et al. Outcomes of video assisted thoracic surgical decortications in 274 patients with tuberculous empyema. Ann Thorac Cardiovasc Surg 2015;21:223-8.
8. Rena O, Casadio C. Chronic pleural empyema: which is the role for surgery? Past and present. Eur J Cardiothorac Surg 2010;38:237.

9. Cardillo G, Carleo F, Carbone L, Di Martino M, Salvadori L, Petrella L, et al. Chronic postpneumonic pleural empyema comparative merits of thoracoscopic versus open decortication. Eur J Cardiothorac Surg 2009;36:914-8.

10. Zahid I, Nagendran M, Routledge T, Scarci M. Comparison of video-assisted thoracoscopic surgery and open surgery in the management of primary empyema.

11. Gokce M, Okur E, Baysungur V, Ergene G, Sevilgen G, Halezeroglu S. Lung decortication for chronic empyaema: effects on pulmonary function and thoracic asymmetry in the late period. Eur J Cardiothorac Surg 2009;36(4):754-8.

12. Choi SS, Kim DJ, Kim KD, Chung KY. Change in pulmonary function following empyemectomy and decortications in tuberculous and non-tuberculous chronic empyema thoracis. Yonsei Med J 2004 31;45(4):643-8.

13. Rzyman W, Skokowski J, Romanowicz G, Lass P, Dziadziuszko R. Decortication in chronic pleural empyema - effect on lung function. Eur J Cardiothorac Surg 2002;21:502-7.

14. Okada M, Tsubota N, Yoshimuro M, Miyamoto Y, Yamagishi H, Satake S. Surgical treatment for chronic pleural empyema. Surg Today 2000;30:506-10.

15. Kho P, Karunanantham J, Leung M, Lim E. Debridement alone without decortication can achieve lung re-expansion in patients with empyema: an observational study. Interact Cardiovasc Thorac Surg 2011;12(5):724-7.

16. Yang HC, Han J, Lee S, Lee JM, Cho S, Kim DJ, et al.. Evaluation of decortication in patients with chronic tuberculous empyema by three-dimensional computed tomography densitometry. Thorac Cardiovasc Surg 2013;61(2):159-66.

17. Kim DJ, Im JG, Goo JM, Lee HJ, Hou SY, Song JW. Chronic tuberculous empyema: relationships between preoperative CT findings and postoperative improvement measured by pulmonary function testing. Clinical Radiol 2005;60, 503-7. 
